\title{
Practical Exploration of Integrating Practical Teaching into Innovation and Entrepreneurship Education in Colleges and Universities
}

\author{
Li Lei \\ Human Resources Office, Jiangsu University, Zhenjiang, China
}

Email address:

627679349@qq.com

\section{To cite this article:}

Li Lei. Practical Exploration of Integrating Practical Teaching into Innovation and Entrepreneurship Education in Colleges and Universities. Science Journal of Education. Vol. 9, No. 1, 2021, pp. 14-19. doi: 10.11648/j.sjedu.20210901.13

Received: January 28, 2021; Accepted: February 15, 2021; Published: February 23, 2021

\begin{abstract}
In the era of mass entrepreneurship and innovation, the country is vigorously developing innovation and entrepreneurship education to meet the development needs of building an innovative country. At present, innovation and entrepreneurship education courses are generally added in Colleges and universities. However, the current situation of innovation and entrepreneurship education in Colleges and universities is not optimistic. There are many problems, such as generalization of objectives, solidification of means, false content, single evaluation and so on. The practical teaching in Colleges and universities can promote the convergence of innovation and entrepreneurship education objectives, enrich the implementation methods, highlight the professional background, and improve the evaluation methods. Give full play to the functional advantages of practical teaching, focus on the cultivation of College Students' innovation and entrepreneurship project selection ability, the shaping of practice subject consciousness, the integration of professional ability, and the sinking of achievement evaluation index. By looking for the breakthrough point of expanding the practical teaching function, establishing the seminar of innovation and entrepreneurship project selection, shaping the main body consciousness of the team driven by problems, breaking through the scope of practical training to promote the cultivation of professional ability, and improving the evaluation index around the sense of acquisition of college students, a new mode of integrating practical teaching into innovation and entrepreneurship education is constructed.
\end{abstract}

Keywords: Practical Teaching, Innovation and Entrepreneurship Education, Colleges and Universities, Mode Construction

\section{Introduction}

In recent years, innovation and entrepreneurship education has become a new value pursuit of higher education. Colleges and universities vigorously promote innovation and entrepreneurship education, actively encourage college students to start their own businesses, and strive to cultivate students' innovative spirit and practical ability. The state has also issued a series of preferential policies, which play an important role in promoting the employment of college graduates. It can be said that innovation and entrepreneurship education has become the direct driving force of economic development.

Foreign innovation and entrepreneurship education has been relatively perfect, showing multi field, innovative, practical and other characteristics, forming a more comprehensive innovation and entrepreneurship curriculum system and practical methods.
China's innovation and entrepreneurship education started late and is still in the stage of active exploration. Scholars have also made some achievements around innovation and entrepreneurship education. Chen Fuqiang, Liu Junying and other scholars put forward the Countermeasures for the development of innovation and entrepreneurship education from the perspective of the demand for innovation and entrepreneurship education talents under the new normal; Wang Yanxin, Wang Jun and other scholars put forward the solutions and paths by analyzing the problems existing in the current innovation and entrepreneurship education; Wang zhanren, a scholar, takes establishing a new concept as the theoretical core to construct a "broad-spectrum" innovation and entrepreneurship education On the basis of methodology, Gao Yuanhao and Wen Quanjing put forward effective measures from concrete practice, etc. In short, scholars have analyzed the 
connotation, importance and implementation path of innovation and entrepreneurship education from different dimensions, and achieved a series of important results. However, there is less analysis on the problems existing in the current innovation and entrepreneurship education, especially how to play the role of practical teaching. This paper analyzes the shortcomings of innovation and entrepreneurship education in Colleges and universities, highlights the role of practical teaching in promoting innovation and entrepreneurship education, so as to provide a new perspective for innovation and entrepreneurship education of college students.

\section{Recent Status of Education on Innovation and Entrepreneurship in Colleges and Universities}

Under the era theme of mass entrepreneurship and innovation, colleges and universities generally set up innovation and entrepreneurship education courses. As far as the feedback is concerned, although many colleges and universities have developed their own text books for innovation and entrepreneurship education and set up a special teaching team, the effect is not ideal from the perspective of students' sense of acquisition. "The social demand for innovation and entrepreneurship talents is increasing, and the talents trained by innovation and entrepreneurship education can not fully meet the market demand, resulting in the current situation of short supply" [1]. The reason is that the social practicality of innovation and entrepreneurship activities is very strong, and the relatively closed in-class teaching mode adopted by colleges and universities can not meet the requirements of innovation and entrepreneurship education; innovation and entrepreneurship activities need to be carried out with the constant efforts of the whole team members, while the current education mode highlights the individual ideas and spiritual motivation of college students, which obviously does not meet the practical requirements of innovation and entrepreneurship activities; innovation mainly embodies the following aspects In technological innovation and process innovation, entrepreneurship needs to take specific projects as the object, which cannot be embodied in classroom teaching. It is particularly important to tap the practical teaching resources in colleges and universities to make up for the deficiencies in the current innovation and entrepreneurship education.

\section{The Deficiency of Innovation and Entrepreneurship Education in Colleges and Universities}

\subsection{Generalization of Innovation and Entrepreneurship Education Objectives}

Innovation and entrepreneurship education is still a new thing for the talent training mode of colleges and universities, which leads to the lack of generalization of innovation and entrepreneurship education objectives to a certain extent. In the design of education system, the professional background of college students is not taken into account, the source composition of teachers (tutors) is not paid attention to in the implementation of education, and the actual requirements of innovation and entrepreneurship activities are not met in the evaluation of education. "The idea of innovation and entrepreneurship education has not really integrated into the overall education and teaching system of the school, and has not formed an innovation and entrepreneurship education mode integrating comprehensive teaching reform and talent training" [2]. Due to the generalization of educational objectives, the supply side of education lacks sufficient willingness to innovate educational models, which makes the demand side of education lack of efficient learning state. As a vocational education, innovation and entrepreneurship should be based on the working process oriented curriculum design, and the education goal design should be accurate.

\subsection{Solidification of Innovation and Entrepreneurship Education Means}

Many colleges and universities offer innovation and entrepreneurship courses in the form of open courses, with classroom teaching as the main line, teachers as the major subject, and single information feedback as the leading. "Without combining the characteristics of our university, we generally copy the education mode of other universities, emphasizing teaching and neglecting practice, which shows a similar phenomenon, thus affecting the quality of innovation and entrepreneurship education in Colleges and universities" [3]. Innovation and entrepreneurship education should first cultivate college students' interest and knowledge of innovation and entrepreneurship, so that they can fully participate in the classroom to transfer the relevant knowledge of innovation and entrepreneurship. However, the recent education methods lead to many college students taking enough credits as their own responsibility, and taking teachers' subjective preference in Entrepreneurship and innovation teaching as the guidance, which may eventually mislead college students' understanding of innovation and entrepreneurship activities.

\subsection{The Content of Innovation and Entrepreneurship Education Is Fictitious}

At present, the innovation and entrepreneurship education fails to focus on the professional background of college students, and is used to guiding the specific teaching process with the generalized education goal, which leads to the problem of false content in the innovation and entrepreneurship education. The content of innovation and entrepreneurship education is not related to or highly relevant to the professional settings of college students; the connotation of innovation and entrepreneurship education does not conform to the social cognitive structure of college students, or exceeds their cognitive level. "In the practice 
teaching system, it is difficult to combine the professional education of college students with the cultivation of innovation and entrepreneurship ability, and it is difficult to achieve the ideal practice teaching effect" [4]. Such as projects of the international e-commerce under The Belt and Road Initiative and a lot of venture capital projects in social practice, which fail to meet the needs of the society through innovation and entrepreneurship education in universities. The content of innovation and entrepreneurship education can not be satisfied.

\subsection{Single Evaluation of Innovation and Entrepreneurship Education}

The evaluation of College Students' achievements in innovation and entrepreneurship learning is mainly reflected in the form of small papers, innovation and entrepreneurship programs, after class feeling, etc. this model ignores the cultivation of team spirit, ignores the innovation and entrepreneurship activities themselves, has no so-called correct answer, and ignores that students' innovation and entrepreneurship programs can not be evaluated by teachers' personal preferences. Although some colleges and universities have gradually established the evaluation index system, they are still groping, "the evaluation elements are not standard, the evaluation measures are unreasonable, and the operability of the evaluation index is not strong" [5] and other problems still exist.

\section{The role of College Practical Teaching in Promoting Innovation and Entrepreneurship Education}

\subsection{Promote the Convergence of Innovation and Entrepreneurship Education Objectives}

At present, there is the problem of goal generalization in innovation and entrepreneurship education, which is deeply affected in the means, content design and evaluation system of innovation and entrepreneurship education. By excavating the functional advantages of practical teaching in Colleges and universities, we can promote the convergence of innovation and entrepreneurship education goals. The logic is that practical teaching constitutes an important part of the cultivation of professional ability of students in colleges and universities, and is relative to the internal vocational education of innovation and entrepreneurship education. The constituent elements of practical teaching items, means and evaluation can be rooted in the professional background of college students "The organic integration of professional education and innovation and entrepreneurship education, adjust the professional curriculum, excavate and enrich the innovation and entrepreneurship education resources of various professional courses" [6], so as to highlight the specialization and post characteristics of innovation and entrepreneurship education, and promote the role of innovation and entrepreneurship education in converging its educational objectives.

\subsection{Enrich the Implementation of Innovation and Entrepreneurship Education Means}

In recent years, with the strategic adjustment of talent training concept and training mode in undergraduate colleges, vocational ability training constitutes the value orientation of current undergraduate education. Under the influence of the value orientation of vocational education, both engineering majors and liberal arts majors have carried out exploration and Reform in deepening the practical teaching mode. To promote innovation and entrepreneurship education with practical teaching will inevitably enrich the implementation mode of innovation and entrepreneurship education due to the optimization and improvement of practical teaching mode itself. Through practical teaching, we should be able to change the status of College Students' participation in innovation and entrepreneurship education, and stimulate their interest and willingness in learning, "through continuous learning accumulation, we can master new professional knowledge, broaden new fields, master new technology and adapt to new environment" [7].

\subsection{Highlight the Professional Background of Innovation and Entrepreneurship Education Content}

"The integration of innovation and entrepreneurship education and professional education is the key point" [8]. Practical teaching enhances the specialization and post orientation of innovation and entrepreneurship education, encourages college students to choose innovation and entrepreneurship materials within the scope of their majors, and gives full play to their professional knowledge reserve, which helps to form a start-up team. In terms of project selection and content design, practical teaching is not only related to theoretical teaching, but also has the independent function orientation of practical teaching, which strengthens the ability training of college students based on the working process. It can be seen that the use of practical teaching to promote the development of innovation and entrepreneurship education can effectively highlight the professional background of innovation and entrepreneurship education content.

\subsection{Improve the Implementation Method of Innovation and Entrepreneurship Education Evaluation}

When exploring the evaluation methods of innovation and entrepreneurship education, we need to focus on how to compare with the innovation and entrepreneurship practice results. Colleges and universities should define their own functional boundaries when conducting innovation and entrepreneurship education. In the functional orientation of cultivating students' Initial Innovation and entrepreneurship quality, the evaluation objects of team cooperation ability and team plan making ability pursued by practical teaching can improve the implementation methods of innovation and entrepreneurship education evaluation. 


\section{The Focus of Practical Teaching Driven by Innovation and Entrepreneurship Education}

\subsection{Focus on the Cultivation of College Students' Innovation and Entrepreneurship Project Selection Ability}

When promoting innovation and entrepreneurship education, practical teaching in Colleges and universities needs to complete the established teaching tasks. The cultivation of innovation and entrepreneurship project selection ability is the embodiment of the expansion of teaching functions. Taking innovation and entrepreneurship practical behaviors as the guidance to investigate the focus of practical teaching, and selecting suitable projects within the professional scope is the primary problem faced by innovation and entrepreneurship. Therefore, market demand orientation and all kinds of resource constraints should constitute the premise of Cultivating College Students' project selection ability. In practice teaching, we need to simulate the real market environment to provide an environment for college students to cultivate their ability of project selection.

\subsection{Focus on the Shaping of College Students' Innovation and Entrepreneurship Practice Subject Consciousness}

Innovation and entrepreneurship education should concentrate on promoting College Students' interest and awareness of participation, and focus on Shaping College Students' knowledge of innovation and entrepreneurship practice, so that they can truly become thinkers and executors in innovation and entrepreneurship activities. "The foothold of innovation and entrepreneurship education lies in the awakening of College Students' subject consciousness, and the increase of the number of entrepreneurs and the improvement of the success rate of entrepreneurship are the results of the awakening of subject consciousness"[9], and enhancing students' sense of participation and acquisition has become the premise of the design of practical training implementation scheme, which support a platform for the shaping of the subject consciousness of innovation and entrepreneurship practice. The formation of subject consciousness is also rooted in the form of social practice, and the practice in the form of team cooperation is bound to shape their team consciousness.

\subsection{Focus on the Integration of College Students' Professional Ability in the Process of Innovation and Entrepreneurship}

Making efforts to choose innovation and entrepreneurship projects under students' professional background can not only give play to their professional knowledge advantages, but also enhance the practice of the idea of professional education in undergraduate stage. Focusing on the ability requirements of innovation and entrepreneurship practice, it centered on the promotion of professional knowledge application ability, professional problem exploration ability and professional knowledge extension ability. "In the process of teaching, teachers should design relevant situations based on knowledge content, stimulate students' innovative thinking in the learning process, and enhance their subjective initiative in the learning process"[10]. In the practical teaching of colleges and universities, efforts should be made in the course design, in the problem presupposition of practical training projects, and in the implementation of the scheme, so as to promote them to obtain the cultivation of the above abilities in practical training.

\subsection{Focus on the Evaluation Index of College Students' Innovation and Entrepreneurship Achievements}

The evaluation can not only reflect the level of innovation and entrepreneurship education in colleges and universities, but also force out the behavior preference of teachers in innovation and entrepreneurship education. After defining the function orientation of colleges and universities in innovation and entrepreneurship education, we should sink the innovation and entrepreneurship achievement index, so that it can be linked with the education function of colleges and universities, and make an accurate evaluation of the basic capacity of innovation and entrepreneurship obtained by college students.

\section{The Construction of Practical Teaching Mode in Colleges and Universities}

\subsection{Find the Breakthrough Point to Expand the Practical Teaching Function}

Under the school-based requirements, colleges and universities need to find the breakthrough point to expand the practical teaching function, and integrate the inner sense of innovation and entrepreneurship education into the practical teaching projects with different professional and disciplinary backgrounds. "Excavate and enrich the innovation and entrepreneurship education resources of various professional courses, infiltrate the concept and content of entrepreneurship education in professional education teaching, and strengthen innovation and entrepreneurship education in the process of imparting professional knowledge" [11]. Taking the practical teaching of economics and management as an example, we can focus on cultivating students' innovation and entrepreneurship awareness in the freshman training, on cultivating students' innovation and entrepreneurship ideas in the sophomore training, and on cultivating students' innovation and entrepreneurship execution in the junior training. Take this as the line, refine the practical teaching content of freshmen, sophomores and juniors, and realize the expansion effect of practical teaching around the promotion of innovation and entrepreneurship awareness, idea design and improvement of executive ability, through "setting up entrepreneurship courses in a hierarchical and phased system, and promoting students' Entrepreneurship work in an organized and planned way" [12]. 


\subsection{Establish a Seminar on Innovation and Entrepreneurship Project Selection}

The seminar of innovation and entrepreneurship project selection should be set up in the practical teaching of sophomore stage. Sophomores have obtained the basic professional knowledge reserve. They have a certain understanding of their professional prospects and related innovation and entrepreneurship projects, and they are more qualified to cultivate their innovation and entrepreneurship project selection ability. In the procedure of innovation and entrepreneurship project selection under the simulated market environment, college students are required to complete market research, project feasibility analysis and other work. They are in the sophomore stage and have such working ability. The seminar should be carried out through the way of leaderless collective negotiation, where teachers act as an inspiration, questioning and guidance. "In the process of professional teaching, teachers should set as many questions with multiple answers as possible, and guide students to analyze problems from multiple perspectives by virtue of their own divergent thinking ability" [10].

\subsection{Shaping the Subject Consciousness of the Team Driven by Problems}

The function of practical teaching in Colleges and universities is to provide the organizational environment and process management of innovation and entrepreneurship activities for college students. Practical teaching should shape the subject consciousness of team members under the problem driven. It can focus on the participation consciousness of the simulated innovation and entrepreneurship project, the division and cooperation consciousness in the team cooperation, and the emotion control ability in the face of team differences. Teachers should assign the team leader according to the team members and the implementation plan of innovation and entrepreneurship project, and the team leader should divide the work among the members. In the practical teaching, the competition pattern between groups should be appropriately introduced. For example, for the entrepreneurial projects of start-ups, the annual profit quota should be used as an important basis for the innovation and entrepreneurship effectiveness of each group in the simulated operation and management of the information platform.

\subsection{Breaking Through the Scope of Practical Training and Promoting the Cultivation of Professional Ability}

College practical teaching can only provide necessary organizational environment and process management for innovation and entrepreneurship education. In order to enhance the driving force of practical teaching, we need to make a breakthrough of the scope of practical training to enhance the advancement of College Students' professional ability training. Around the innovation and entrepreneurship project, the innovation and entrepreneurship training activities are extended to extracurricular activities with the group as the unit and the group leader as the manager. The implementation cycle of the project does not exceed the training teaching cycle. Many colleges and universities have introduced information platform to simulate the process of innovation and entrepreneurship. In the process of professional ability cultivation, it is evident to underline the cultivation of College Students' project budget fund management ability and material procurement management ability. These abilities are closely related to risk control in innovation and entrepreneurship practice activities, and the focus of risk control is to control the risk of project fund circulation. "In the process of enterprise training, through personal participation in practice, students have a certain understanding of the development and workflow of the enterprise, and have laid a good foundation for their future career" [13].

\subsection{Improve the Evaluation Index Around College Students' Sense of Acquisition}

In order to spur the interests of college students to join in the training of innovation and entrepreneurship, in the improvement of the evaluation index, we need to take the sense of practical training of college students as the object and sink the evaluation index system. "The index element is a comprehensive system, multi-link and multi-factor interrelated evaluation system, and the evaluation system formed by it has the characteristics of multi-source evaluation" [14]. Firstly, students should be included in the main category of practical teaching evaluation, and their score weight in the evaluation of practical teaching effect should be increased; secondly, students' evaluation data should be obtained by online questionnaire survey and teaching evaluation; thirdly, practical teaching results should be written according to the real scheme structure and content. The key points for teachers to score the scheme are the practicability evaluation analysis of project selection, the financing method of project, the fund allocation and the realization of profit model, etc.

The practical teaching in colleges and universities should also be carried out under an open system, through the integration of resources, play a multi-faceted effect, and improve the innovation and entrepreneurship ability of college students. We should give full play to the leading role of government departments, make use of government resources, provide policy and institutional support and preferential funds for the construction of entrepreneurial base, and provide assistance for college students' innovation and entrepreneurship. Seek deep integration with enterprises, explore the platform built by schools and enterprises, establish a new mode of cooperation between colleges and enterprises, and jointly build innovation and entrepreneurship gathering area and incubation area. We should build an innovation and entrepreneurship culture ecosystem, optimize the cultivation of innovation and entrepreneurship ideas and school talent mode, establish a multi-department linkage coordination mechanism, and make mutual communication and coordination among various departments available. 


\section{Conclusion}

With the in-depth reform of education, college students' innovation and entrepreneurship education has become an important task of talent training in Colleges and universities. At present, we need to pay attention to the functional advantages of practical teaching, and integrate practical training into innovation and entrepreneurship education. To promote the development of innovation and entrepreneurship education by expanding the effectiveness of practical training teaching is not only a means to carry out innovation and entrepreneurship education for college students, but also an important part of the internal development of colleges and universities. The practical teaching in Colleges and universities can promote the convergence of innovation and entrepreneurship education objectives, enrich the implementation methods, highlight the professional background, and improve the evaluation methods. Give full play to the functional advantages of practical teaching, focus on the cultivation of College Students' innovation and entrepreneurship project selection ability, the shaping of practice subject consciousness, the integration of professional ability, and the sinking of achievement evaluation index. The implementation mode of practical teaching in Colleges and universities can focus on: looking for the breakthrough point to expand the function of practical teaching, establishing a seminar on the selection of innovation and entrepreneurship projects, shaping the subject consciousness of the team driven by problems, breaking through the scope of practical training to promote the cultivation of professional ability, and focusing on the evaluation index of College Students' sense of perfection.

\section{References}

[1] Chen Fuqiang. Analysis and Countermeasures of the development of innovation and entrepreneurship education in Colleges and Universities under the new normal [J]. Innovation and entrepreneurship education, 2018 (12): 22.

[2] Wang Yanxin. Reflection and mode construction of innovation and entrepreneurship education in Colleges and universities [J]. China University teaching, 2015 (4): 6.

[3] Hu Xiaomeng. Realistic reflection and coping strategies of innovation and entrepreneurship education in Colleges and universities from the perspective of "precise supply" [J]. Theoretical research and practice of innovation and entrepreneurship, 2019 (1): 52.

[4] Wu Zhicheng. Research on the practical teaching system of colleges and Universities Based on the cultivation of "entrepreneurship and innovation" talents [J]. Education modernization, 2020 (1): 28.

[5] Gao Yuanhao. Construction and practice of quality evaluation index system for practical teaching base construction in applied local universities $[\mathrm{J}]$. Contemporary education practice and teaching research, 2019 (10): 181.

[6] Chen Haidan. On innovation and entrepreneurship education for college students [J]. Labor security world, 2015 (10): 11.

[7] Chen Fuqiang. Analysis and Countermeasures of the development of innovation and entrepreneurship education in Colleges and Universities under the new normal [J]. Innovation and entrepreneurship education, 2018 (12): 23.

[8] Hua jucui. Construction and practice of engineering practice teaching system in local universities from the perspective of innovation and entrepreneurship [J]. Modern education management, 2017 (4): 92.

[9] Wang Jun. innovation and entrepreneurship education in Colleges and universities focuses on breakthrough in accuracy [J]. Education and career, 2017 (5): 69.

[10] Full text. On the cultivation path and strategy of College Students' innovation and entrepreneurship ability under the new situation $[\mathrm{J}]$. Contemporary education practice and teaching research, 2017 (12): 56.

[11] Wang zhanren. The overall concept of innovation and entrepreneurship education in Colleges and universities [J]. China higher education research, 2015 (7): 75-76.

[12] Xiao Fengling. The current situation of Vocational College Students' entrepreneurial quality and the improvement countermeasures [J]. Hebei Vocational Education, 2020 (2): 88.

[13] Hong Mei. Research on the practical teaching system of colleges and universities for the cultivation of innovation and entrepreneurship ability $[\mathrm{J}]$. Journal of Changchun Normal University, 2017 (10): 119.

[14] Gao Yuanhao. Construction and practice of quality evaluation index system of practical teaching base construction in applied local universities $[\mathrm{J}]$. Contemporary education practice and teaching research, 2019 (10): 182. 